\title{
Review \\ Radiosensitization and Radioprotection by Curcumin in Glioblastoma and Other Cancers
}

\author{
Vasiliki Zoi ${ }^{1}$, Vasiliki Galani ${ }^{2}$, Pericles Tsekeris ${ }^{3}$, Athanasios P. Kyritsis ${ }^{1}\left(\mathbb{D}\right.$ and George A. Alexiou ${ }^{1, *}$ \\ 1 Neurosurgical Institute, University of Ioannina, 45500 Ioannina, Greece; vasozoi95@gmail.com (V.Z.); \\ thkyrits@uoi.gr (A.P.K.) \\ 2 Department of Anatomy Histology-Embryology, School of Medicine, University of Ioannina, \\ 45110 Ioannina, Greece; vgalani@uoi.gr \\ 3 Department of Radiation Oncology, University of Ioannina, 45110 Ioannina, Greece; ptsekeri@uoi.gr \\ * Correspondence: galexiou@uoi.gr
}

check for updates

Citation: Zoi, V.; Galani, V.; Tsekeris, P.; Kyritsis, A.P.; Alexiou, G.A. Radiosensitization and Radioprotection by Curcumin in Glioblastoma and Other Cancers. Biomedicines 2022, 10, 312 . https://doi.org/10.3390/ biomedicines10020312

Academic Editor: Jun Lu

Received: 7 January 2022

Accepted: 26 January 2022

Published: 28 January 2022

Publisher's Note: MDPI stays neutral with regard to jurisdictional claims in published maps and institutional affiliations.

Copyright: (C) 2022 by the authors. Licensee MDPI, Basel, Switzerland. This article is an open access article distributed under the terms and conditions of the Creative Commons Attribution (CC BY) license (https:// creativecommons.org/licenses/by/ $4.0 /)$.

\begin{abstract}
Radiation therapy plays an important role in almost every cancer treatment. However, radiation toxicity to normal tissues, mainly due to the generation of reactive free radicals, has limited the efficacy of radiotherapy in clinical practice. Curcumin has been reported to possess significant antitumor properties. Although curcumin can sensitize cancer cells to irradiation, healthy cells are much less sensitive to this effect, and thus, curcumin is thought to be a potent, yet safe anti-cancer agent. In this review, a summary of the role of curcumin as both a radiosensitizer and radioprotector has been presented, based on the most recent data from the experimental and clinical evaluation of curcumin in different cancer cell lines, animal models, and human patients.
\end{abstract}

Keywords: curcumin; cancer; radiation therapy; radiosensitizer

\section{Introduction}

Radiation therapy (RT) plays a pivotal role in cancer treatment, along with surgery and chemotherapy. Radiotherapy induces DNA damage either directly by ionization or indirectly through the generation of reactive oxygen species (ROS) [1]. It has been used for over 100 years for the treatment of solid tumors, including cancers of the skin, breast, prostate, and brain, and has also been used to treat leukemia, gliomas, and lymphoma. Novel radiotherapy modalities, including proton and carbon ions, and stereotactic radiotherapy have also, gained the interest of scientists. Traditionally, RT has been delivered in a fractionated manner, and the total dose is broken up into daily doses five times a week. In some cases, however, accelerated RT has been found to increase the overall survival of patients and local control of tumors, particularly head and neck cancer [2,3].

Although RT remains the most effective non-surgical technique in the treatment of malignant tumors, radiation toxicity to normal tissues, different side effects affecting various organs such as skin, and the development of significant radioresistance in cancer cells are limiting its efficacy [4,5]. The development of radioresistance is associated with different mechanisms, including epigenetic alterations or the activation of survival signaling pathways [1].

Ionizing radiation causes damage to normal tissues primarily through the direct deposition of energy into vital macromolecules or the generation of reactive free radicals. [6] Those radicals react with biomolecules, like proteins and lipids, and cause oxidative damage in them [7]. Although fractionated irradiation in combination with improved treatment modalities has made radiotherapy safer than before, it is still important to broaden the therapeutic window between normal tissue damage and tumor suppression [8,9]. Two strategies are of clinical importance: radiosensitization of tumor cells without sensitizing normal cells and radioprotection of normal cells [10]. 
Curcumin (Figure 1) (also known as diferuloylmethane) is extracted from the turmeric plant and possesses several health benefits, most of which have been attributed to its anti-inflammatory properties [11]. Curcumin has also been used in the management of various skin conditions, such as alopecia, skin infections, and atopic dermatitis [12,13]. In cancer treatment, curcumin has been studied alone and/or in combination with chemotherapeutic agents and radiation therapy [14,15]. Although curcumin can sensitize cancer cells to irradiation, healthy cells are much less sensitive to this effect and thus, curcumin is considered a potent, yet safe anti-cancer agent [16-18]. Moreover, curcumin has been found to possess radioprotective properties, since it can lessen inflammatory toxicities associated with radiotherapy, like dermatitis, mucositis, and myelosuppression [19,20]. In this review, we focus on this dual mode of action of curcumin and its analogs in relation to radiotherapy and have summarized the most recent evidence of its role as both a radiosensitizer and radioprotective agent.<smiles>COc1cc(/C=C/C(=O)CC(=O)/C=C/c2ccc(O)c(OC)c2)ccc1O</smiles>

Figure 1. Chemical structure of curcumin.

\section{Radiosensitization by Curcumin}

Radiosensitizers are molecules that can amplify radiation-induced cellular damage [21]. Several radiosensitizers, including paclitaxel and cisplatin, have been studied with the aim to unravel their mechanism of action and the possible effect on normal cells surrounding the tumor. Most of those compounds, however, exhibit side effects that exclude them for use as a treatment option for all irradiated patients [22,23]. Moreover, resistance factors, such as the repair of radiation-induced DNA damage make the successful killing of all remaining cells capable of tumor regrowth almost inevitable [24].

Among the most thoroughly studied radiosensitizing agents is curcumin. Curcumin has been studied for its anti-cancer properties in different types of cancer and almost all evidence of radiosensitization come from laboratory data [11]. Curcumin can radiosensitize cells through different defined pathways. (Figure 2) Ionizing radiation has been reported to modify intracellular signaling mainly through modification of the activity of RASassociated proteins, growth factors, and their receptors, like epidermal growth factor (EGFR), and transforming growth factor- $\beta$ (TGF- $\beta$ ) [25]. Curcumin can suppress the gene expression of EGFR, and downregulate the TGF- $\beta$ pathway, thus leading to inhibition of cancer-associated fibroblasts (CAF)-mediated cancer progression [26].

Ionizing radiation enhances the production of reactive oxygen species (ROS) that can cause DNA damage through the development of double-stranded breaks. After that, proteins related to DNA reparation, like DNA-dependent protein kinase are activated to act in favor of the DNA damage response pathway [27]. Curcumin can induce ROS generation and suppress DNA repair machinery, thus leading to increased radiation-induced cell death $[28,29]$.

Apoptosis is the most common type of cell death induced by radiation in malignant tumors [30]. Although irradiation mostly induces the intrinsic apoptotic pathway, depending on both cell type and dose, the extrinsic apoptotic pathway (death receptor-mediated) can also, be involved [31]. Curcumin has been found to induce apoptosis through a series of actions on different signaling pathways, including upregulation of both the expression and activity of p53, regulation of the anti-apoptotic PI3K signaling, and suppression of the activity of NF- $\mathrm{KB}$ and COX-2 [32]. 


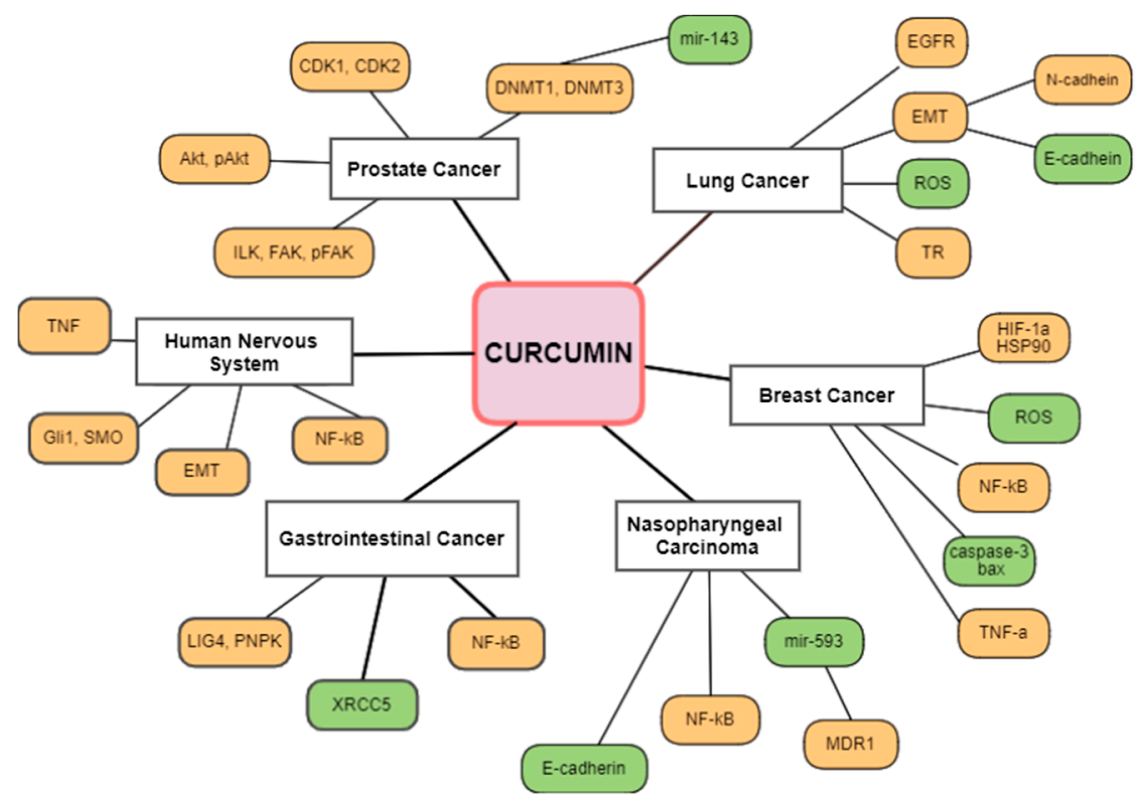

Molecular targets upregulated by curcumin

Molecular targets downregulated by curcumin

Figure 2. Molecular targets of curcumin contribute to radiosensitization in different cancers. Abbreviations: CDK: cyclin-dependent kinase; Akt: protein kinase B; ILK: integrin-linked kinase; FAK: focal adhesion kinase; DNMT: DNA methyltransferase; EGFR: endothelial growth factor receptor; EMT: epithelial-mesenchymal transition; ROS: reactive oxygen species; TR: trypanothione reductase; HIF-

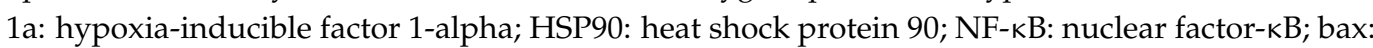
bcl-2-like protein 4, TNF-a: tumor necrosis factor-a; MDR1: multidrug resistance protein 1; XRCC5: X-ray repair cross-complementing 5; LIG4: ligase 4; PNPK: polynucleotide kinase/phosphatase; Gli1: glioma-associated oncogene homologue 1; SMO: smoothened.

\section{Curcumin as a Radiosensitizer in Various Malignant Tumors and Glioblastoma}

In human non-small cell lung cancer A549 cells, curcumin $(10 \mu \mathrm{M})$ has been shown to promote cell death following $x$-ray irradiation through inhibition of the epidermal growth factor receptor (EGFR)-associated pathway [33]. EGFR has been recently related to radioresistance in different tumors, however, the exact mechanism following this relationship requires further investigation [34]. In another study, A549 cells were exposed to irradiation to incite an epithelial-mesenchymal transition (EMT) model [35]. EMT plays a crucial role in metastasis which is characterized by the upregulation of mesenchymal molecular markers, like N-cadherin, and downregulation of epithelial molecular markers, including E-cadherin [36]. Curcumin was found to suppress radiation-induced EMT resulting in the inhibition of NSCLC migration and invasion [35].

When a metabolically stable analog of curcumin known as dimethoxycurcumin (DIMC), was used in combination with radiation, both an apoptotic and mitotic death in A549 cells was observed as a result of the inhibition of thioredoxin reductase activity. When thioredoxin reductase is inhibited, the oxidized form of thioredoxin accumulates in cells, resulting in increased oxidative stress. When combined with 4Gy radiation, DIMC $(2.5 \mu \mathrm{M})$ significantly increased the levels of ROS, whereas a slowdown in DNA repair was also, observed [37]. In a xenograft model of A549 cells, curcumin-loaded nanoparticles enhanced the tumor growth inhibitory effect of radiation, mainly through induction of apoptosis [38].

The radiosensitizing effect of curcumin on nasopharyngeal carcinoma (NPC) cells has been studied to unravel whether the exact mechanism is associated with multidrug 
resistance gene 1 (MDR1) and microRNA-593. At $10 \mu \mathrm{mol} / \mathrm{L}$, curcumin upregulated the expression of miR-593, resulting in the depression of MDR1 expression, which may promote radiosensitivity of NPC cells. When curcumin $(100 \mathrm{mg} / \mathrm{kg})$ was given prior to 4 Gy irradiation in a transplanted tumor model in vivo, a significant tumor growth inhibition was observed in the irradiation plus curcumin group compared to the irradiation only group. [39] In another study, where human NPC cell line CNE-2 was used, curcumin enhanced radiosensitization through modulation of the circular RNAs (circRNAs) network. [40] CircRNAs are known to take part in the cellular irradiation response and some of them, including KIRKOS-71 and KIRKOS-73 have been studied as promising diagnostic radiotherapy biomarkers [41].

In three breast cancer cell lines (MCF10A, MCF7, and MDA-MB-231 BC) curcuminloaded solid nanoparticles $(2.5-10 \mu \mathrm{M})$ were used in combination with increasing doses of irradiation (2-9 Gy). Based on a transcriptomic and metabolomics study, the combination of curcumin and radiotherapy resulted in the deregulation of molecules involved in the induction of apoptosis, in the inflammatory process, in the cell cycle, and in tyrosine metabolism in both MCF7 and MDA-MB-231 BC cell lines. In the non-tumorigenic MCF10A cell line, the effect of the combination treatment was mostly related to lysine degradation and transcriptional misregulation [42]. In breast cancer stem cells, curcumin combined with glucose nanogold particles managed to significantly reduce radiotherapy resistance under hypoxic conditions. The molecular mechanism underlying this effect was found to be related to inhibition of the expression of both hypoxia-inducible factor 1-alpha (HIF-1a) and heat shock protein 90 (HSP90) proteins and increase in the levels of ROS [43].

In cervical cancer, curcumin has been studied as a potent mTOR inhibitor when given together with irradiation. When a human cervical cancer cell line (HeLa) was treated with increased curcumin concentrations followed by irradiation (2 Gy) using a linear accelerator, increased cell cytotoxicity was observed compared to treatment with irradiation or curcumin alone [44]. In a randomized control trial that included cervical carcinoma stage IIB-IIIB patients, the levels of survivin, which is an important anti-apoptotic protein, were assessed in patients receiving curcumin and radiation as opposed to those treated with irradiation alone. Decreased levels of this protein were observed in $75 \%$ of patients having received the combination, whereas, in the group treated with irradiation alone, $60 \%$ of patients showed increased levels of survivin [45].

In prostate cancer, the radiosensitizing effect of curcumin has been correlated to epigenetic activation of miR-143. Pretreatment of PC-3, DU145, and LNCaP cells with curcumin, prior to exposure to irradiation resulted in the reduction in the expression of prototypic DNA methyltransferase DNMT1 and DNMT3B, both of which contribute to the hypermethylation of the miR-143/miR-145 cluster. Furthermore, curcumin pretreatment increased radiation-induced apoptosis [46]. In another study, where DU145 and PC-3 cells were treated with low doses of curcumin $(0.1-0.4 \mu \mathrm{g} / \mathrm{mL})$ prior to irradiation with $1.65 \mathrm{~J} / \mathrm{cm}^{2}$ visible light, it was observed that the combination resulted in significant tumor growth suppression, and both adhesion and migration were hindered [47].

Curcumin has shown significant radiosensitizing properties in tumors developed in the human nervous system. When LN229 and U251 glioma cells were treated with curcumin $(20 \mu \mathrm{M})$ after exposure to $\gamma$-irradiation, the irradiation-stimulated epithelial-mesenchymal transition (EMT) process was suppressed through inhibition of the Hedgehog signaling pathway, which is characterized by an increase in E-cadherin levels. Moreover, combined treatment with curcumin and ionizing radiation reduced both the cell migration and invasion abilities of both cell lines. The same effect on the EMT process was observed when combination treatment was given in intracranial glioma models of nude mice [48]. In another study that included U87 and T98 human glioma cells, the combination treatment of curcumin and radiotherapy resulted in increased cytotoxicity and a more prominent G2/M arrest compared to individual treatment [49]. The synergistic effects of curcumin and radiotherapy were also validated in an orthotopic F98/FGT glioma-bearing rat model. 
Curcumin enhanced the effects of radiotherapy resulting in increased suppression of the growth of in situ brain tumors and transplanted glioma cells alike [50].

Several studies have shown the radiosensitizing effects of curcumin in gastrointestinal cancers. In five different human esophageal squamous cell lines ESCC-07, ESCC-12, ESCC-19, ESCC-27, and ESCC-31, curcumin increased radiation-induced apoptotic death primarily through inhibition of the NF- $\mathrm{kB}$ signaling pathway. Pretreatment with curcumin also suppressed tumor progression and decreased both the tumor volume and weight of ESCC-07 xenograft mice that were previously exposed to fractionated radiotherapy [51]. When low doses of curcumin $(2.5 \mu \mathrm{M})$ were combined with radiation in human colon cancer HT-29 cells, a stronger inhibitory effect on cell proliferation was observed, due to modulation of expression of DNA repair-related genes, including Cyclin $\mathrm{H}(\mathrm{CCNH}), \mathrm{DNA}$ Ligase 4 (LIG4) and Polynucleotide Kinase 3'-Phosphatase (PNKP). When HT-29 bearing mice were treated with curcumin and irradiation, the combined treatment resulted in higher intratumoral apoptosis and suppression of neoplastic growth [52]. In human pancreatic cancer lines Panc- 1 and MiaPaCa-2, curcumin enhanced radiation-induced apoptosis and increased the G2/M-fraction at the irradiation time point in both cell lines [53].

Curcumin has been reported to increase the radiosensitivity of renal ACHN cancer cells through suppression of the NF- $\mathrm{kB}$ signaling pathway and modulation of the associated protein levels, like COX-2 and Bcl-2. In ACHN tumor-bearing nude mice, curcumin and irradiation treatment resulted in decreased tumor volume and enhanced apoptotic death [54]. Inhibition of cell viability and clonogenic survival was observed in urinary bladder cancer T24 cells after treatment with curcumin $(10 \mu \mathrm{M})$ in combination with radiation. This effect was attributed to the downregulation of miR-1246 expression, resulting in inhibition of the p53 nuclear transcription factor [55]. A summary of the most recent studies on the radiosensitizing effects of curcumin on different cancer models is depicted in Table 1.

Table 1. Radiosensitizing effects of curcumin on different cancer models.

\begin{tabular}{|c|c|c|c|c|}
\hline Cancer Site & Subject & Curcumin Dosage & Effect & Ref. \\
\hline \multirow[t]{3}{*}{ Lung } & Human A549 cells & $10 \mu \mathrm{M}$ & $\begin{array}{l}\text { Increase in IR-induced reduction of } \\
\text { cell viability via inhibition of EGFR } \\
\text { protein }\end{array}$ & [33] \\
\hline & Human A549 cells & 5-20 $\mu \mathrm{M}$ & $\begin{array}{l}\text { Inhibition of migration, invasion through } \\
\text { suppression of radiation-induced EMT }\end{array}$ & [35] \\
\hline & Xenograft model of A549 cells & $20 \mathrm{uM}$ & Induction of apoptosis & [38] \\
\hline \multirow[t]{2}{*}{ Nasopharynx } & $\begin{array}{l}\text { Human nasopharyngeal } \\
\text { carcinoma (NPC) cells }\end{array}$ & $10 \mu \mathrm{M}$ & $\begin{array}{l}\text { Increase in radiosensitivity through } \\
\text { depression of MDR1 expression }\end{array}$ & [39] \\
\hline & Human NPC cell line CNE-2 & $20 \mu \mathrm{M}$ & $\begin{array}{l}\text { Increase in IR-induced cell death through } \\
\text { modulation of circRNAs }\end{array}$ & [40] \\
\hline \multirow[t]{2}{*}{ Breast } & $\begin{array}{l}\text { Human MCF10A, MCF7 and } \\
\text { MDA-MB-231 BC cells }\end{array}$ & $2.5-10 \mu \mathrm{M}$ & $\begin{array}{l}\text { Deregulation of molecules involved in the } \\
\text { induction of apoptosis, in the } \\
\text { inflammatory process, in the cell cycle, } \\
\text { and tyrosine metabolism }\end{array}$ & [42] \\
\hline & Breast cancer stem cells & $30 \mu \mathrm{M}$ & $\begin{array}{l}\text { Reduction of RT resistance through } \\
\text { inhibition of HIF-1a, HSP90 }\end{array}$ & [43] \\
\hline \multirow[t]{2}{*}{ Prostate } & $\begin{array}{l}\text { Human PC-3, DU145, and } \\
\text { LNCaP cells }\end{array}$ & $30 \mu \mathrm{M}$ & $\begin{array}{l}\text { Increase in IR-induced } \\
\text { apoptosis/reduction in the expression of } \\
\text { DNMT1 and DNMT3B }\end{array}$ & [46] \\
\hline & DU145 and PC-3 cells & $0.1-0.4 \mu \mathrm{g} / \mathrm{mL}$ & $\begin{array}{l}\text { Tumor growth suppression, decreased } \\
\text { invasion, and migration }\end{array}$ & [47] \\
\hline Cervix & Human HeLa cells & $40 \mu \mathrm{M}$ & $\begin{array}{l}\text { Increased cell cytotoxicity of the } \\
\text { combination }\end{array}$ & [44] \\
\hline
\end{tabular}


Table 1. Cont.

\begin{tabular}{|c|c|c|c|c|}
\hline Cancer Site & Subject & Curcumin Dosage & Effect & Ref. \\
\hline & $\begin{array}{l}\text { Cervical carcinoma stage } \\
\text { IIB-IIIB patients }\end{array}$ & $4 \mathrm{~g} /$ day & Decreased levels of surviving & [45] \\
\hline \multirow[t]{3}{*}{ CNS } & LN229 and U251 glioma cells & $20 \mu \mathrm{M}$ & $\begin{array}{l}\text { Reduction in cell migration and } \\
\text { invasion/inhibition of the Hedgehog } \\
\text { signaling pathway }\end{array}$ & [48] \\
\hline & $\begin{array}{l}\text { U87 and T98 human glioma } \\
\text { cells }\end{array}$ & $10-20 \mu \mathrm{M}$ & Increased cytotoxicity and G2/M arrest & [49] \\
\hline & $\begin{array}{l}\text { Orthotopic F98/FGT } \\
\text { glioma-bearing rat model. }\end{array}$ & $5-20 \mu \mathrm{M}$ & $\begin{array}{c}\text { Suppression of the growth of in situ brain } \\
\text { tumors }\end{array}$ & {$[50]$} \\
\hline \multirow[t]{2}{*}{ Esophagus } & $\begin{array}{l}\text { Human ESCC-07, ESCC-12, } \\
\text { ESCC-19, ESCC-27 and } \\
\text { ESCC-31 cell lines }\end{array}$ & $10 \mu \mathrm{M}$ & $\begin{array}{l}\text { Increase in IR-induced } \\
\text { apoptosis/Inhibition of Nf-Kb signaling }\end{array}$ & {$[51]$} \\
\hline & ESCC-07 xenograft mice & $10 \mu \mathrm{M}$ & Decrease in tumor volume and weight & [51] \\
\hline \multirow[t]{2}{*}{ Colon } & $\begin{array}{l}\text { Human colon cancer HT-29 } \\
\text { cells }\end{array}$ & $2.5 \mu \mathrm{M}$ & $\begin{array}{l}\text { Inhibition of cell } \\
\text { proliferation/modulation of expression of } \\
\text { DNA repair-related genes }\end{array}$ & [52] \\
\hline & HT-29 bearing mice & $2.5 \mu \mathrm{M}$ & $\begin{array}{l}\text { Intratumoral apoptosis and suppression } \\
\text { of neoplastic growth }\end{array}$ & {$[52]$} \\
\hline Pancreas & $\begin{array}{c}\text { Human Panc-1 and MiaPaCa-2 } \\
\text { cells }\end{array}$ & 6 or $12 \mu \mathrm{M}$ & Increased cytotoxicity and $\mathrm{G} 2 / \mathrm{M}$ arrest & [53] \\
\hline \multirow[t]{2}{*}{ Kidney } & Renal ACHN cancer cells & $5-80 \mu \mathrm{M}$ & $\begin{array}{l}\text { Increased cell death, suppression of the } \\
\text { NF- } k B \text { signaling pathway }\end{array}$ & [54] \\
\hline & $\begin{array}{l}\text { ACHN tumor-bearing nude } \\
\text { mice }\end{array}$ & $5-80 \mu \mathrm{M}$ & $\begin{array}{c}\text { Decrease in tumor volume increased } \\
\text { apoptosis }\end{array}$ & [54] \\
\hline Urinary Bladder & $\begin{array}{l}\text { Urinary bladder cancer T24 } \\
\text { cells }\end{array}$ & $10 \mu \mathrm{M}$ & $\begin{array}{l}\text { Inhibition of p53 nuclear transcription } \\
\text { factor }\end{array}$ & [55] \\
\hline
\end{tabular}

\section{Radioprotection by Curcumin}

Radiotherapy plays an important role in cancer treatment. The fraction of all cancer survivors who received radiation increased from $24 \%$ in 2000 to $29 \%$ in 2020 [56]. Normal tissue toxicity is, however, a limiting factor for receiving sufficient doses of radiation to kill the tumor [57]. Common radiation toxicities include dermatitis, pneumonitis, myelosuppression, secondary tumors, mucositis, and skin irritation. Since most of these toxicities are inflammatory in nature, they are amenable to the anti-inflammatory properties of curcumin [58].

During radiotherapy, about $90 \%$ of patients experience acute skin reactions [59]. The mechanism of radiation-induced skin toxicities has been related to apoptosis and necrosis even weeks after irradiation. [60] In a recent study, where 40 rats were exposed to curcumin 1 day before irradiation to 3 consecutive days after irradiation, the levels of antioxidant enzymes, including catalase (CAT), superoxide dismutase (SOD), and malondialdehyde (MDA), were found to be considerably elevated after curcumin treatment, suggesting that curcumin reacted to the radiotherapy-induced oxidative damage [61]. The therapeutic effect of topical application of curcumin after gamma-radiation exposure was assessed in a mini-pig model. Curcumin was applied topically to the irradiated skin $\left(200 \mathrm{mg} / \mathrm{cm}^{2}\right)$ twice a day for 35 days. The curcumin-treated group showed inhibition of the irradiation-induced increases in NF- $\mathrm{kB}$ and COX-2 expression. Moreover, treatment with curcumin stimulated wound healing, thus improving the clinical appearance of the biopsy wound more quickly compared to the vehicle-treated group [62] (Table 2).

Radiation dermatitis is characterized by erythema, dry desquamation, ulceration and occurs in $90 \%$ of patients undergoing RT [63]. In a randomized, placebo-controlled, blinded 
study of 191 breast cancer patients, curcumin was applied topically on the irradiated skin daily for a week after irradiation completion. In patients with high breast separation $(\geq 25 \mathrm{~cm})$, who may have the worst skin reactions, curcumin was found to be effective in minimizing RT dermatitis and pain [64]. In another randomized, double-blinded, placebocontrolled trial of 686 breast cancer patients, however, in which patients received 500-mg capsules of curcumin three times daily for up to 1-week after radiation therapy, no significant reduction in RT dermatitis severity was observed compared to the placebo group [65] (Table 2).

Radiation-induced lung injury poses a great threat to patients exposed to total body irradiation. Pneumonitis usually appears some months after radiotherapy, whereas fibrosis may appear a few years later [66]. Curcumin has been found to mitigate both pneumonitis and fibrosis in rats through downregulation of the expression of IL-4, IL4Ra1, DUOX1, and DUOX2 [67]. Interleukin (IL)- 4 has been related to the development of radiation-induced inflammation, while dual oxidase 1 and 2 (DUOX1 and 2), are responsible for chronic $\mathrm{H}_{2} \mathrm{O}_{2}$ production $[68,69]$. The radio-protective effects of curcumin in this rat model were also attributed to its ability to attenuate macrophages as well as lymphocyte infiltration [67]. In another recent study, where curcumin was loaded in a mesoporous polydopamine nanoparticles (CMPN) system and administrated intratracheally to the lung of rats after exposure to $15 \mathrm{~Gy}$ 60Co $\gamma$-ray radiation on the chest area, a reduction in proinflammatory cytokines, and malondialdehyde (MDA), along with an increase in SOD was observed [70] (Table 2).

Oral mucositis (OM) is caused by injury to salivary glands and arterioles, followed by the release of ROS and inflammatory cytokines. Patients under head and neck radiotherapy are more susceptible to the development of OM, although the exact risk depends on multiple factors, including gender, age, tobacco use, and radiotherapy dosage [71]. In a recent clinical study, 50 patients under chemotherapy were divided into two groups according to their exposure or not to head and neck radiotherapy. All patients received $80 \mathrm{mg}$ of curcumin nanomicelle capsules twice a day for 7 weeks. The results showed that in patients who were under chemotherapy and head and neck radiotherapy, curcumin administration managed to significantly decrease the OM severity [72]. Similar results were presented by Charantinath et al. who evaluated the efficacy and safety of a curcumin gel in the alleviation of $\mathrm{OM}$ in cancer patients undergoing radiochemotherapy [73]. The efficacy of curcumin in reducing OM in cancer patients has also been attested in a triple-blind, pilot randomized controlled trial, which included 74 head and neck cancer patients scheduled to receive RT. The use of $0.1 \%$ curcumin mouthwash managed to decrease the risk of getting the onset of OM by 50\% [74] (Table 2).

Curcumin may also protect lymphocytes, the most RT-susceptible type of blood cells against genotoxicity. When 21 patients with differentiated thyroid carcinoma were treated with I-131 (activity $5.5 \mathrm{GBq}$ ), and then received curcumin at a dosage of $160 \mathrm{mg} /$ day for 10 days, exhibited a significantly lower frequency of micronuclei in peripheral blood lymphocytes compared to the placebo group [75]. In another study, human peripheral blood lymphocytes (HPBLs) were treated with increased curcumin concentrations $(0.125-50 \mu \mathrm{g} / \mathrm{mL})$ prior to exposure to $3 \mathrm{~Gy}$ of $\gamma$-radiation. Curcumin pre-treatment inhibited the formation of different free radicals, including hydroxyl $(\mathrm{OH})$, nitric oxide (NO), and 2,2'-diphenyl-1-picrylhydrazyl (DPPH) in a dose-dependent manner [76]. Similar results were observed in a study involving human blood cells obtained from healthy male donors when treated with curcumin-encapsulated liposomes at an optimal concentration of $30 \mu \mathrm{g} / \mathrm{mL}$ prior to exposure to gamma Cobalt-60 irradiation. A significant decrease in micronuclei formation was noted that was independent of the irradiation dose [77] (Table 2).

The radioprotective effect of curcumin on rat heart tissue has been investigated by Kolivand et al. Twenty rats were given $150 \mathrm{mg} / \mathrm{kg}$ curcumin for seven consecutive days after exposure to $\gamma$-rays (15 Gy). After 10 weeks, an increase in the infiltration of lymphocytes and macrophages was observed, as well as a decrease in the expression of Duox1 and Duox2. The levels of both IL-4 protein and its receptor were also, decreased in the curcumin-treated group. Those results signify a reduction in popular radiation-induced heart injury markers [78]. Oral administration of curcumin has also been related to de- 
creased risk of developing irradiation-induced hepatic or liver damages. Essawy et al. found that curcumin treatment shows hepatoprotective effects against radiation-induced hepatotoxicity in rats, through regulation of the therapeutic targets CYP2E1, Nrf2, and NF- $\kappa B$, whereas Li et al. found that curcumin treatment prior to radiation can prevent liver damages, mainly through the modulation of the NF- $\mathrm{BB}$ pathway and reduction of oxidative stress (upregulation of SOD, CAD and GSH levels in the curcumin-treated group) $[79,80]$ (Table 2).

Table 2. Recent studies on radiotherapy adverse reactions prevention/management with curcumin. $\uparrow$, upregulation; $\downarrow$, downregulation.

\begin{tabular}{|c|c|c|c|c|}
\hline Adverse Reaction & Subject & Curcumin Dosage & Mechanism/Conclusion & Ref \\
\hline $\begin{array}{l}\text { Acute skin reactions } \\
\text { (prevention) }\end{array}$ & 40 rats & $\begin{array}{l}150 \mathrm{mg} / \mathrm{kg} 1 \text { day before to } \\
3 \text { days post-radiation }\end{array}$ & $\uparrow$ antioxidant enzymes (CAT, SOD, MDA) & [61] \\
\hline $\begin{array}{l}\text { Acute skin reactions } \\
\quad \text { (management) }\end{array}$ & mini-pig model & $\begin{array}{l}200 \mathrm{mg} / \mathrm{cm}^{2} \text { twice a day } \\
\text { for } 35 \text { days after RT }\end{array}$ & $\begin{array}{c}\downarrow N F-\kappa B \text { and COX-2 expression, } \uparrow \text { wound } \\
\text { healing }\end{array}$ & [62] \\
\hline $\begin{array}{l}\text { Radiation dermatitis } \\
\text { (prevention) }\end{array}$ & $\begin{array}{l}191 \text { breast cancer } \\
\text { patients }\end{array}$ & $\begin{array}{l}\text { Curcumin gel } 3 \text { times daily } \\
\text { for } 1 \text { week after RT }\end{array}$ & $\begin{array}{l}\downarrow \text { RDS and Pain scores in patients with } \\
\text { high breast separation }(\geq 25 \mathrm{~cm})\end{array}$ & [64] \\
\hline $\begin{array}{l}\text { Radiation dermatitis } \\
\quad \text { (prevention) }\end{array}$ & $\begin{array}{l}686 \text { breast cancer } \\
\text { patients }\end{array}$ & $\begin{array}{l}500 \text { mg three times daily } \\
\text { for } 1 \text { week after RT }\end{array}$ & $\begin{array}{l}\text { No sig. difference between curcumin and } \\
\text { placebo in RDS }\end{array}$ & [65] \\
\hline $\begin{array}{l}\text { Radiation } \\
\text { pneumonitis/fibrosis }\end{array}$ & 20 rats & $\begin{array}{c}150 \mathrm{mg} / \mathrm{kg} \text { for } 4 \text { days } \\
\text { before and } 6 \text { consecutive } \\
\text { days after RT }\end{array}$ & $\downarrow$ IL-4, IL4Ra1, DUOX1 and 2 expression & [67] \\
\hline Radiation pneumonitis & 20 rats & $2 \mathrm{mg}$ i.t. $5 \mathrm{~h}$ pre-irradiation & $\begin{array}{c}\downarrow \text { proinflammatory cytokines, MDA, and } \\
\uparrow \text { SOD expression }\end{array}$ & [69] \\
\hline $\begin{array}{l}\text { Oral mucositis } \\
\text { (treatment) }\end{array}$ & $\begin{array}{l}50 \text { head and neck } \\
\text { cancer patients }\end{array}$ & $\begin{array}{l}80 \mathrm{mg} \text { of curcumin } \\
\text { nanomicelle capsules twice } \\
\text { a day for } 7 \text { weeks }\end{array}$ & $\downarrow$ OM severity and pain & [72] \\
\hline $\begin{array}{l}\text { Oral mucositis } \\
\text { (treatment) }\end{array}$ & $\begin{array}{l}40 \text { patients with } \\
\text { OM }\end{array}$ & $\begin{array}{l}\text { Gel containing } 10 \mathrm{mg} \text { of } \\
\text { curcumin, } 3 \text { times a day for } \\
2 \text { weeks }\end{array}$ & $\downarrow$ OM severity & [73] \\
\hline $\begin{array}{l}\text { Lymphocytes } \\
\text { genotoxicity } \\
\text { (treatment) }\end{array}$ & $\begin{array}{l}21 \text { patients with } \\
\text { differentiated } \\
\text { thyroid carcinoma } \\
\text { (DTC) }\end{array}$ & $\begin{array}{l}160 \mathrm{mg} / \text { day for } 10 \text { days } \\
\text { post-RT }\end{array}$ & $\begin{array}{l}\downarrow \text { frequency of micronuclei in peripheral } \\
\text { blood lymphocytes }\end{array}$ & [75] \\
\hline $\begin{array}{l}\text { Lymphocytes } \\
\text { genotoxicity } \\
\text { (prevention) }\end{array}$ & $\begin{array}{l}\text { Human peripheral } \\
\text { blood lymphocytes } \\
\text { (HPBLs) }\end{array}$ & $\begin{array}{c}0.125-50 \mu \mathrm{g} / \mathrm{mL} \text { prior to } \\
\mathrm{RT}\end{array}$ & $\begin{array}{l}\downarrow \text { formation of } \mathrm{OH}, \mathrm{NO}, \mathrm{DPPH}, \\
\text { micronuclei }\end{array}$ & [76] \\
\hline $\begin{array}{l}\text { Heart tissue toxicity } \\
\quad \text { (prevention) }\end{array}$ & 20 rats & $\begin{array}{l}150 \mathrm{mg} / \mathrm{kg} \text { curcumin for } \\
\text { 7days after RT }\end{array}$ & $\begin{array}{l}\downarrow \text { Duox1 and Duox2, IL-4 protein and its } \\
\text { receptor } \\
\uparrow \text { infiltration lymphocytes, macrophages }\end{array}$ & [78] \\
\hline $\begin{array}{l}\text { Hepatic toxicity } \\
\text { (prevention) }\end{array}$ & 20 rats & $\begin{array}{c}100 \mathrm{mg} / \mathrm{kg} \text { orally for } 21 \\
\text { days before RT }\end{array}$ & $\begin{array}{l}\text { Regulation of Nrf2, mir-122, } \mathrm{Ca}^{2+} \text { level, } \\
\text { NF- } \mathrm{kB}\end{array}$ & [79] \\
\hline $\begin{array}{l}\text { Liver toxicity } \\
\text { (treatment) }\end{array}$ & 30 rats & $\begin{array}{c}30 \mathrm{mg} / \mathrm{kg} \text { for } 2 \text { weeks once } \\
\text { a day post-RT }\end{array}$ & $\begin{array}{l}\uparrow \text { SOD, CAD, GSH, Bcl-2 } \\
\downarrow \text { TNF- } \alpha, \text { IL- } 1 \beta, \text { IL- } 6, \\
\downarrow \text { p-NF- } \mathrm{B} / \mathrm{NF}-\kappa \mathrm{B}\end{array}$ & [80] \\
\hline
\end{tabular}

\section{Conclusions and Future Perspectives}

A substantial volume of scientific evidence exists that curcumin acts as both a radiosensitizer to tumors and radioprotector to normal cells. Moreover, several beneficial properties of curcumin, including ease of oral administration, its lack of systemic toxicity, and low cost, make this natural polyphenol a promising adjuvant agent for the treatment of various human cancers, in combination with standard radiation therapy. Exploitation of the radiosensitizing potential of curcumin could not only result in a better clinical outcome, par- 
ticularly in cases where significant radioresistance to standard therapy has been observed, but also, in the reduction of the radiation doses that are required for the achievement of therapeutic effects. That can, in turn, lower both the extent and severity of adverse effects related to radiotherapy.

Mechanistically, the radiosensitizing effects of curcumin are achieved via modulation of different molecular targets which are involved in the proliferation, angiogenesis, apoptosis, and metastasis of cancer cells. The exact mechanism of action highly depends on the malignant cell type, and the timing of curcumin treatment. In most cases, pretreatment with curcumin before exposure to irradiation is required in order to achieve the maximum antitumor activity. In terms of radioprotection, the anti-inflammatory nature of curcumin has been the key to understanding this module of action, since most adverse effects related to RT, including dermatitis, oral mucositis, and pneumonitis are inflammatory in nature. However, it is evident that the molecular mechanisms underlying the radioprotective and radiosensitizing effects of curcumin should be fully understood in order to develop a novel combined radiotherapeutic strategy for cancer patients.

A factor that has still limited the clinical value of curcumin is its low bioavailability. Curcumin exhibits poor absorption, extensive metabolism, and rapid elimination from the body. Even when administrated at doses of $12 \mathrm{~g} /$ day, the bioavailability of curcumin remains distinctly poor [81]. However, modern strategies have been developed that aim to increase the limited bioavailability of curcumin (e.g., liposomal, molecular analogs, and conjugated forms). In that turn, the encapsulation of this compound into nanosized carriers has been shown to improve the direct delivery of curcumin to tumor sites considerably [82]. When a water-soluble curcumin formulation that consisted of curcumin, cellulosic derivatives, and a widely used hydrophilic carrier was made, a 46-fold increase in its oral absorption was observed [83]. Other strategies to help overcome the issue of low bioavailability have been reported by several scientific groups. Singh et al. developed a silica nanoparticle-CUR complex conjugated with hyaluronic acid that enhanced curcumin cytotoxicity on COLO-205 cancer cells, and increased its stability and uptake, as well [84]. Jyoti et al. showed that chitosan microspheres of CUR improved solubility and increased its cytotoxicity in HT-29 cells, [85] whereas Shinde and Devarajan developed a docosahexaenoic acid-mediated microemulsion of curcumin and showed that it can effectively release curcumin to the brain and inhibit the proliferation of human glioma U-87MG cells [86].

Although the radiosensitizing effect of curcumin has been widely explored by different scientific groups in several cancer models, curcumin-related oncological clinical studies listed in clinicaltrails.gov are also worth mentioning. For example, in a randomized, double-blind, placebo-controlled trial curcumin was given to prostate cancer patients with intermittent androgen deprivation resulting in a decrease in the levels of prostate-specific antigen (PSA) (NCT03211104) [87]. Topical application of curcumin showed a significant therapeutic effect in patients with oral submucous fibrosis particularly in combination with triamcinolone and hyaluronidase [88]. In a multi-site, randomized, placebo-controlled, blinded study of 191 breast cancer patients, topical application of curcumin was found to help reduce radiotherapy-associated dermatitis and pain [64]. There is also, accumulating evidence to suggest the potential anti-neoplastic activity of curcumin against HNCs [89,90].

Furthermore, the protective action of curcumin against radiation-induced damages on normal tissues is of significant clinical value. In that respect, the use of modern strategies to increase bioavailability is extremely important. When curcumin-encapsulated liposomes were prepared using commercial phosphatidylcholine, an enhanced radioprotective effect against genotoxicity caused by Gamma Cobalt-60 irradiation in human blood cells was observed [77]. Since curcumin is a safe and highly tolerable natural compound, it could be administrated in combination with traditional radiotherapy to improve the clinical outcome of cancer patients in the future. However, clinical trials in humans are needed to fully assess the radiosensitizing and radioprotective properties of this compound. 


\begin{abstract}
Author Contributions: Conceptualization, V.Z. and G.A.A.; data curation, V.Z., A.P.K., V.G. and P.T.; writing original draft preparation, V.Z., G.A.A. and V.G.; writing-review and editing, G.A.A., A.P.K., V.G. and P.T. All authors have read and agreed to the published version of the manuscript.
\end{abstract}

Funding: This research received no external funding.

Institutional Review Board Statement: Not applicable.

Informed Consent Statement: Not applicable.

Conflicts of Interest: The authors declare no conflict of interest.

\title{
References
}

1. Kargiotis, O.; Geka, A.; Rao, J.S.; Kyritsis, A.P. Effects of irradiation on tumor cell survival, invasion and angiogenesis. J. Neuro-Oncol. 2010, 100, 323-338. [CrossRef] [PubMed]

2. Blyth, B.J.; Cole, A.J.; MacManus, M.P.; Martin, O.A. Radiation therapy-induced metastasis: Radiobiology and clinical implications. Clin. Exp. Metastasis 2018, 35, 223-236. [CrossRef]

3. Lyhne, N.M.; Primdahl, H.; Kristensen, C.A.; Andersen, E.; Johansen, J.; Andersen, L.J.; Evensen, J.; Mortensen, H.R.; Overgaard, J. The DAHANCA 6 randomized trial: Effect of 6 vs. 5 weekly fractions of radiotherapy in patients with glottic squamous cell carcinoma. Radiother. Oncol. 2015, 117, 91-98. [CrossRef] [PubMed]

4. Bennardo, L.; Passante, M.; Cameli, N.; Cristaudo, A.; Patruno, C.; Nisticò, S.P.; Silvestri, M. Skin Manifestations after Ionizing Radiation Exposure: A Systematic Review. Bioengineering 2021, 8, 153. [CrossRef] [PubMed]

5. Levin, V.A.; Maor, M.H.; Thall, P.F.; Yung, W.K.; Bruner, J.; Sawaya, R.; Kyritsis, A.P.; Leeds, N.; Woo, S.; Rodriguez, L.; et al. Phase II study of accelerated fractionation radiation therapy with carboplatin followed by vincristine chemotherapy for the treatment of glioblastoma multiforme. Int. J. Radiat. Oncol. Biol. Phys. 1995, 33, 357-364. [CrossRef]

6. Pham-Huy, L.A.; He, H.; Pham-Huy, C. Free radicals, antioxidants in disease and health. Int. J. Biomed. Sci. 2008, 4, 89-96. [PubMed]

7. Gupta, J.K.; Upmanyu, N.; Patnaik, A.K.; Mazumder, P.M. Evaluation of antiulcer activity of Leucas lavandulifolia on mucosal lesion in rat. Asian, J. Pharm. Clin. Res. 2010, 3, 118-120.

8. Emami, B.; Lyman, J.; Brown, A.; Coia, L.; Goitein, M.; Munzenrider, J.E.; Shank, B.; Solin, L.J.; Wesson, M. Tolerance of normal tissue to therapeutic irradiation. Int. J. Radiat. Oncol. Biol. Phys. 1991, 21, 109-122. [CrossRef]

9. Groves, M.D.; Maor, M.H.; Meyers, C.; Kyritsis, A.P.; Jaeckle, K.A.; Yung, W.K.; Sawaya, R.E.; Hess, K.; Bruner, J.M.; Peterson, P.; et al. A phase II trial of high-dose bromodeoxyuridine with accelerated fractionation radiotherapy followed by procarbazine, lomustine, and vincristine for glioblastoma multiforme. Int. J. Radiat. Oncol. Biol. Phys. 1999, 45, 127-135. [CrossRef]

10. Maier, P.; Hartmann, L.; Wenz, F.; Herskind, C. Cellular Pathways in Response to Ionizing Radiation and Their Targetability for Tumor Radiosensitization. Int. J. Mol. Sci. 2016, 17, 102. [CrossRef]

11. Zoi, V.; Galani, V.; Lianos, G.D.; Voulgaris, S.; Kyritsis, A.P.; Alexiou, G.A. The Role of Curcumin in Cancer Treatment. Biomedicines 2021, 9, 1086. [CrossRef] [PubMed]

12. Nistico, S.; Tamburi, F.; Bennardo, L.; Dastoli, S.; Schipani, G.; Caro, G.; Fortuna, F.C.; Rossi, A. Treatment of telogen effluvium using a dietary supplement containing Boswellia serrata, Curcuma longa, and Vitis vinifera: Results of an observational study. Dermatol. Ther. 2019, 32, 3. [CrossRef] [PubMed]

13. Vollono, L.; Falconi, M.; Gaziano, R.; Iacovelli, F.; Dika, E.; Terracciano, C.; Bianchi, L.; Campione, E. Potential of Curcumin in Skin Disorders. Nutrients 2019, 11, 2169.

14. Dhandapani, K.M.; Mahesh, V.B.; Brann, D.W. Curcumin suppresses growth and chemoresistance of human glioblastoma cells via AP-1 and NFkappaB transcription factors. J. Neurochem. 2007, 102, 522-538. [CrossRef] [PubMed]

15. Zhang, L.; Ding, X.; Huang, J.; Jiang, C.; Cao, B.; Qian, Y.; Cheng, C.; Dai, M.; Guo, X.; Shao, J. In vivo Radiosensitization of human glioma U87 cells induced by upregulated expression of DUSP-2 after treatment with curcumin. Curr. Signal Transduct. Ther. 2015, 10, 119-125. [CrossRef]

16. Li, M.; Zhang, Z.; Hill, D.L.; Wang, H.; Zhang, R. Curcumin, a dietary component, has anticancer, chemosensitization, and radiosensitization effects by down-regulating the MDM2 oncogene through the PI3K/mTOR/ETS2 pathway. Cancer Res. 2007, 67, 1988-1996. [CrossRef]

17. Zanotto-Filho, A.; Braganhol, E.; Edelweiss, M.I.; Behr, G.A.; Zanin, R.; Schröder, R.; Simões-Pires, A.; Battastini, A.M.; Moreira, J.C. The curry spice curcumin selectively inhibits cancer cells growth in vitro and in preclinical model of glioblastoma. J. Nutr. Biochem. 2012, 23, 591-601. [CrossRef]

18. Gersey, Z.C.; Rodriguez, G.A.; Barbarite, E.; Sanchez, A.; Walters, W.M.; Ohaeto, K.C.; Komotar, R.J.; Graham, R.M. Curcumin decreases malignant characteristics of glioblastoma stem cells via induction of reactive oxygen species. BMC Cancer 2017, 17, 99. [CrossRef]

19. Jurenka, J.S. Anti-inflammatory properties of curcumin, a major constituent of Curcuma longa: A review of preclinical and clinical research. Altern. Med. Rev. 2009, 14, 141-153.

20. Shehzad, A.; Rehman, G.; Lee, Y.S. Curcumin in inflammatory diseases. BioFactors 2013, 39, 69-77. [CrossRef] 
21. Levin, V.A.; Yung, W.K.; Bruner, J.; Kyritsis, A.; Leeds, N.; Gleason, M.J.; Hess, K.R.; Meyers, C.A.; Ictech, S.A.; Chang, E.; et al. Phase II study of accelerated fractionation radiation therapy with carboplatin followed by PCV chemotherapy for the treatment of anaplastic gliomas. Int. J. Radiat. Oncol. Biol. Phys. 2002, 53, 58-66. [CrossRef]

22. Khafif, A.V.I.; Hurst, R.; Kyker, K.; Fliss, D.M.; Gil, Z.I.V.; Medina, J.E. Curcumin: A new radio-sensitizer of squamous cell carcinoma cells. Otolaryngol. Head Neck Surg. 2005, 132, 317-321. [CrossRef] [PubMed]

23. Jagetia, G.C. Radioprotection and radiosensitization by curcumin. Adv. Exp. Med. Biol. 2007, 595, 301-320. [PubMed]

24. Schmidt-Ullrich, R.K.; Contessa, J.N.; Dent, P.; Mikkelsen, R.B.; Valerie, K.; Reardon, D.B.; Bowers, G.; Lin, P.S. Molecular mechanisms of radiation-induced accelerated repopulation. Radiat. Oncol. Investig. 1999, 7, 321-330. [CrossRef]

25. Coleman, C.N. Radiation oncology: Linking technology and biology in the treatment of cancer. Acta Oncol. 2002, 41, 6-13. [CrossRef] [PubMed]

26. Jamalzaei, P.; Valojerdi, M.R.; Montazeri, L.; Baharvand, H. Effects of alginate concentration and ovarian cells on in vitro development of mouse preantral follicles: A factorial study. Int. J. Fertil. Steril. 2020, 13, 330-338.

27. Santivasi, W.L.; Xia, F. Ionizing radiation-induced DNA damage, response, and repair. Antioxid. Redox Signal. 2014, 21, 251-259. [CrossRef]

28. Zeng, Y.; Du, Q.; Zhang, Z.; Ma, J.; Han, L.; Wang, Y.; Yang, L.; Tao, N.; Qin, Z. Curcumin promotes cancer-associated fibroblasts apoptosis via ROS-mediated endoplasmic reticulum stress. Arch. Biochem. Biophys. 2020, 694, 108613. [CrossRef]

29. Nakamae, I.; Morimoto, T.; Shima, H.; Shionyu, M.; Fujiki, H.; Yoneda-Kato, N.; Yokoyama, T.; Kanaya, S.; Kakiuchi, K.; Shirai, T.; et al. Curcumin Derivatives Verify the Essentiality of ROS Upregulation in Tumor Suppression. Molecules 2019, $24,4067$. [CrossRef]

30. Cho, W.; Kim, M.S.; Lee, K.H.; Park, S.J.; Shin, H.J.; Lee, Y.J.; Kim, S.B.; Son, Y.; Kim, C.H. Ionizing radiation attracts tumor targeting and apoptosis by radiotropic lysyl oxidase traceable nanoparticles. Nanomed. Nanotechnol. Biol. Med. 2020, $24,102141$. [CrossRef]

31. Takasawa, R.; Nakamura, H.; Mori, T.; Tanuma, S. Differential apoptotic pathways in human keratinocyte HaCaT cells exposed to UVB and UVC. Apoptosis 2005, 10, 1121-1130. [CrossRef] [PubMed]

32. Mortezaee, K.; Salehi, E.; Mirtavoos-Mahyari, H.; Motevaseli, E.; Najafi, M.; Farhood, B.; Rosengren, R.J.; Sahebkar, A. Mechanisms of apoptosis modulation by curcumin: Implications for cancer therapy. J. Cell. Physiol. 2019, 234, 12537-12550. [CrossRef] [PubMed]

33. Cai, Y.; Sheng, Z.; Liang, S. Radiosensitization effects of curcumin plus cisplatin on non-small cell lung cancer A549 cells. Oncol. Lett. 2019, 18, 529-534. [CrossRef] [PubMed]

34. Rego, R.L.; Foster, N.R.; Smyrk, T.C.; Le, M.; O'Connell, M.J.; Sargent, D.J.; Windschitl, H.; Sinicrope, F.A. Prognostic effect of activated EGFR expression in human colon carcinomas: Comparison with EGFR status. Br. J. Cancer 2010, 102, 165-172. [CrossRef] [PubMed]

35. Deng, X.; Chen, C.; Wu, F.; Qiu, L.; Ke, Q.; Sun, R.; Duan, Q.; Luo, M.; Luo, Z. Curcumin Inhibits the Migration and Invasion of Non-Small-Cell Lung Cancer Cells through Radiation-Induced Suppression of Epithelial-Mesenchymal Transition and Soluble E-Cadherin Expression. Technol. Cancer Res. Treat. 2020, 19, 1533033820947485. [CrossRef] [PubMed]

36. Cui, X.; Lin, Q.; Huang, P.; Liang, Y. Antiepithelial-Mesenchymal Transition of Herbal Active Substance in Tumor Cells via Different Signaling. Oxidative Med. Cell. Longev. 2020, 2020, 9253745. [CrossRef] [PubMed]

37. Jayakumar, S.; Patwardhan, R.S.; Pal, D.; Sharma, D.; Sandur, S.K. Dimethoxycurcumin, a metabolically stable analogue of curcumin enhances the radiosensitivity of cancer cells: Possible involvement of ROS and thioredoxin reductase. Biochem. Biophys. Res. Commun. 2016, 478, 446-454. [CrossRef]

38. Cuixia, W.; Yun, Z.; Chong, Z.; Yifan, Z.; Xiang, H.; Jun, L.; Haitao, Y. Enhanced Radiosensitization Effect of Curcumin Delivered by PVP-PCL Nanoparticle in Lung Cancer. J. Nanomater. 2017, 8, 9625909.

39. Fan, H.; Shao, M.; Huang, S.; Liu, Y.; Liu, J.; Wang, Z.; Diao, J.; Liu, Y.; Tong, L.; Fan, Q.; et al. MiR-593 mediates curcumin-induced radiosensitization of nasopharyngeal carcinoma cells via MDR1. Oncol. Lett. 2016, 11, 3729-3734. [CrossRef]

40. Zhu, D.; Shao, M.; Yang, J.; Fang, M.; Liu, S.; Lou, D.; Gao, R.; Liu, Y.; Li, A.; Lv, Y.; et al. Curcumin Enhances Radiosensitization of Nasopharyngeal Carcinoma via Mediating Regulation of Tumor Stem-like Cells by a CircRNA Network. J. Cancer 2020, 11, 2360-2370. [CrossRef]

41. O'Leary, V.B.; Smida, J.; Matjanovski, M.; Brockhaus, C.; Winkler, K.; Moertl, S.; Ovsepian, S.V.; Atkinson, M.J. The circRNA interactome-innovative hallmarks of the intra- and extracellular radiation response. Oncotarget 2017, 8, 78397-78409. [CrossRef] [PubMed]

42. Minafra, L.; Porcino, N.; Bravatà, V.; Gaglio, D.; Bonanomi, M.; Amore, E.; Cammarata, F.P.; Russo, G.; Militello, C.; Savoca, G.; et al Radiosensitizing effect of curcumin-loaded lipid nanoparticles in breast cancer cells. Sci. Rep. 2019, 9, 11134. [CrossRef] [PubMed]

43. Yang, K.; Liao, Z.; Wu, Y.; Li, M.; Guo, T.; Lin, J.; Li, Y.; Hu, C. Curcumin and Glu-GNPs Induce Radiosensitivity against Breast Cancer Stem-Like Cells. BioMed Res. Int. 2020, 2020, 3189217. [CrossRef] [PubMed]

44. Assad, D.X.; Borges, G.A.; Avelino, S.R.; Guerra, E.N.S. Additive cytotoxic effects of radiation and mTOR inhibitors in a cervical cancer cell line. Pathol. Res. Pract. 2018, 214, 259-262. [CrossRef] [PubMed]

45. Hidayat, Y.M.; Wagey, F.; Suardi, D.; Susanto, H.; Laihad, B.J.; Tobing, M.D.L. Analysis of Curcumin as a Radiosensitizer in Cancer Therapy with Serum Survivin Examination: Randomised Control Trial. Asian Pac. J. Cancer Prev. 2021, 22, 139-143. [CrossRef] 
46. Liu, J.; Li, M.; Wang, Y.; Luo, J. Curcumin sensitizes prostate cancer cells to radiation partly via epigenetic activation of miR-143 and miR-143 mediated autophagy inhibition. J. Drug Target. 2017, 25, 645-652. [CrossRef]

47. Rutz, J.; Benchellal, A.; Kassabra, W.; Maxeiner, S.; Bernd, A.; Kippenberger, S.; Zöller, N.; Chun, F.K.; Juengel, E.; Blaheta, R.A Growth, Proliferation and Metastasis of Prostate Cancer Cells Is Blocked by Low-Dose Curcumin in Combination with Light Irradiation. Int. J. Mol. Sci. 2021, 22, 9966. [CrossRef] [PubMed]

48. Meng, X.; Cai, J.; Liu, J.; Han, B.; Gao, F.; Gao, W.; Zhang, Y.; Zhang, J.; Zhao, Z.; Jiang, C. Curcumin increases efficiency of $\gamma$-irradiation in gliomas by inhibiting Hedgehog signaling pathway. Cell Cycle 2017, 16, 1181-1192. [CrossRef]

49. Zoi, V.; Galani, V.; Vartholomatos, E.; Zacharopoulou, N.; Tsoumeleka, E.; Gkizas, G.; Bozios, G.; Tsekeris, P.; Chousidis, I.; Leonardos, I.; et al. Curcumin and Radiotherapy Exert Synergistic Anti-Glioma Effect In Vitro. Biomedicines 2021, 9, 1562. [CrossRef]

50. Wang, W.H.; Shen, C.Y.; Chien, Y.C.; Chang, W.S.; Tsai, C.W.; Lin, Y.H.; Hwang, J.J. Validation of Enhancing Effects of Curcumin on Radiotherapy with F98/FGT Glioblastoma-Bearing Rat Model. Int. J. Mol. Sci. 2020, 21, 4385. [CrossRef]

51. Liu, G.; Wang, Y.; Li, M. Curcumin sensitized the antitumour effects of irradiation in promoting apoptosis of oesophageal squamous-cell carcinoma through NF-kB signalling pathway. J. Pharm. Pharmacol. 2018, 70, 1340-1348. [CrossRef] [PubMed]

52. Yang, G.; Qiu, J.; Wang, D.; Tao, Y.; Song, Y.; Wang, H.; Tang, J.; Wang, X.; Sun, Y.U.; Yang, Z.; et al. Traditional Chinese Medicine Curcumin Sensitizes Human Colon Cancer to Radiation by Altering the Expression of DNA Repair-related Genes. Anticancer. Res. 2018, 38, 131-136. [PubMed]

53. Schwarz, K.; Dobiasch, S.; Nguyen, L.; Schilling, D.; Combs, S.E. Modification of radiosensitivity by Curcumin in human pancreatic cancer cell lines. Sci. Rep. 2020, 10, 3815. [CrossRef] [PubMed]

54. Li, G.; Wang, Z.; Chong, T.; Yang, J.; Li, H.; Chen, H. Curcumin enhances the radiosensitivity of renal cancer cells by suppressing NF-kB signaling pathway. Biomed. Pharmacother. 2017, 94, 974-981. [CrossRef] [PubMed]

55. Xu, R.; Li, H.; Wu, S.; Qu, J.; Yuan, H.; Zhou, Y.; Lu, Q. MicroRNA-1246 regulates the radio-sensitizing effect of curcumin in bladder cancer cells via activating P53. Int. Urol. Nephrol. 2019, 51, 1771-1779. [CrossRef]

56. Bryant, A.K.; Banegas, M.P.; Martinez, M.E.; Mell, L.K.; Murphy, J.D. Trends in Radiation Therapy among Cancer Survivors in the United States, 2000-2030. Cancer Epidemiol. Biomark. Prev. 2017, 26, 963-970. [CrossRef]

57. FitzGerald, T.J.; Bishop-Jodoin, M.; Laurie, F.; Lukez, A.; O'Loughlin, L.; Sacher, A. Treatment Toxicity: Radiation. Oncol. Emerg. Med. 2019, 33, 1027-1039.

58. Tawfik, S.S.; Abouelella, A.M.; Shahein, Y.E. Curcumin protection activities against $\gamma$-rays-induced molecular and biochemical lesions. BMC Res. Notes 2013, 6, 375. [CrossRef]

59. Ryan, J.L. Ionizing radiation: The good, the bad, and the ugly. J. Investig. Dermatol. 2012, 132, 985-993. [CrossRef]

60. Najafi, M.; Motevaseli, E.; Shirazi, A.; Geraily, G.; Rezaeyan, A.; Norouzi, F.; Rezapoor, S.; Abdollahi, H. Mechanisms of inflammatory responses to radiation and normal tissues toxicity: Clinical implications. Int. J. Radiat. Biol. 2018, 94, 335-356. [CrossRef]

61. Shabeeb, D.; Musa, A.E.; Ali, H.S.A.; Najafi, M. Curcumin Protects Against Radiotherapy-Induced Oxidative Injury to the Skin. Drug Des. Dev. Ther. 2020, 14, 3159-3163. [CrossRef] [PubMed]

62. Kim, J.; Park, S.; Jeon, B.S.; Jang, W.-S.; Lee, S.-J.; Son, Y.; Rhim, K.-J.; Lee, S.I.; Lee, S.-S. Therapeutic effect of topical application of curcumin during treatment of radiation burns in a mini-pig model. J. Vet. Sci. 2016, 17, 435-444. [CrossRef] [PubMed]

63. Kole, A.J.; Kole, L.; Moran, M.S. Acute radiation dermatitis in breast cancer patients: Challenges and solutions. Breast Cancer Targets Ther. 2017, 9, 313-323. [CrossRef] [PubMed]

64. Ryan Wolf, J.; Gewandter, J.S.; Bautista, J.; Heckler, C.E.; Strasser, J.; Dyk, P.; Anderson, T.; Gross, H.; Speer, T.; Dolohanty, L.; et al Utility of topical agents for radiation dermatitis and pain: A randomized clinical trial. Support. Care Cancer 2020, 28, 3303-3311. [CrossRef]

65. Wolf, J.R.; Heckler, C.E.; Guido, J.J.; Peoples, A.R.; Gewandter, J.S.; Ling, M.; Vinciguerra, V.P.; Anderson, T.; Evans, L.; Wade, J.; et al. Oral curcumin for radiation dermatitis: A URCC NCORP study of 686 breast cancer patients. Support Care Cancer 2018, 26, 1543-1552. [CrossRef]

66. Proklou, A.; Diamantaki, E.; Pediaditis, E.; Kondili, E. Radiation Therapy: Impact on Lung Function and Acute Respiratory Failure. In Mechanical Ventilation in Critically Ill Cancer Patients; Springer: Berlin/Heidelberg, Germany, 2018; pp. 33-39.

67. Amini, P.; Saffar, H.; Nourani, M.R.; Motevaseli, E.; Najafi, M.; Taheri, R.A.; Qazvini, A. Curcumin Mitigates Radiation-induced Lung Pneumonitis and Fibrosis in Rats. Int. J. Mol. Cell. Med. 2018, 7, 212-219.

68. Groves, A.M.; Johnston, C.J.; Misra, R.S.; Williams, J.P.; Finkelstein, J.N. Effects of IL-4 on pulmonary fibrosis and the accumulation and phenotype of macrophage subpopulations following thoracic irradiation. Int. J. Radiat. Biol. 2016, 92, 754-765. [CrossRef]

69. Ameziane-El-Hassani, R.; Talbot, M.; de Souza Dos Santos, M.C.; Al Ghuzlan, A.; Hartl, D.; Bidart, J.M.; De Deken, X.; Miot, F.; Diallo, I.; de Vathaire, F. NADPH oxidase DUOX1 promotes long-term persistence of oxidative stress after an exposure to irradiation. Proc. Natl. Acad. Sci. USA 2015, 112, 5051-5056. [CrossRef]

70. Chen, T.; Zhuang, B.; Huang, Y.; Liu, Y.; Yuan, B.; Wang, W.; Yuan, T.; Du, L.; Jin, Y. Inhaled curcumin mesoporous polydopamine nanoparticles against radiation pneumonitis. Acta Pharm. Sin. B 2021, 11, 11. [CrossRef]

71. Chaveli-López, B. Oral toxicity produced by chemotherapy: A systematic review. J. Clin. Exp. Dent. 2014, 6, 81-90. [CrossRef] 
72. Kia, S.J.; Basirat, M.; Saedi, H.S.; Arab, S.A. Effects of nanomicelle curcumin capsules on prevention and treatment of oral mucosits in patients under chemotherapy with or without head and neck radiotherapy: A randomized clinical trial. BMC Complement Med. Ther. 2021, 21, 232. [CrossRef] [PubMed]

73. Charantimath, S. Use of curcumin in Radiochemotherapy induced Oral mucositis patients: A control trial study. Int. J. Med. Health Sci. 2016, 10, 147-152.

74. Shah, S.; Rath, H.; Sharma, G.; Senapati, S.N.; Mishra, E. Effectiveness of curcumin mouthwash on radiation-induced oral mucositis among head and neck cancer patients: A triple-blind, pilot randomised controlled trial. Indian, J. Dent. Res. 2020, 31, 718-727.

75. Farhadi, M.; Bakhshandeh, M.; Shafiei, B.; Mahmoudzadeh, A.; Hosseinimehr, S.J. The Radioprotective Effects of Nano-Curcumin Against Genotoxicity Induced by Iodine-131 in Patients with Differentiated Thyroid Carcinoma (DTC) by Micronucleus Assay, Int. J. Cancer Manag. 2018, 11, e14193.

76. Jagetia, G.C. Antioxidant activity of curcumin protects against the radiation-induced micronuclei formation in cultured human peripheral blood lymphocytes exposed to various doses of $\gamma$-Radiation. Int. J. Radiat. Biol. 2021, 97, 485-493. [CrossRef]

77. Minh-Hiep, N.; Ngoc-Duy, P.; Bingxue, D.; Thi-Huynh-Nga, N.; Chi-Bao, B.; Hadinoto, K. Radioprotective activity of curcuminencapsulated liposomes against genotoxicity caused by Gamma Cobalt-60 irradiation in human blood cells. Int. J. Radiat. Biol. 2017, 93, 1267-1273.

78. Kolivand, S.; Amini, P.; Saffar, H.; Rezapoor, S.; Motevaseli, E.; Najafi, M.; Nouruzi, F.; Shabeeb, D.; Musa, A.E. Evaluating the Radioprotective Effect of Curcumin on Rat's Heart Tissues. Curr. Radiopharm. 2019, 12, 23-28. [CrossRef]

79. Eassawy, M.M.T.; Salem, A.A.; Ismail, A.F.M. Biochemical study on the protective effect of curcumin on acetaminophen and gammairradiation induced hepatic toxicity in rats. Environ. Toxicol. 2021, 36, 748-763. [CrossRef]

80. Li, W.; Jiang, L.; Lu, X.; Liu, X.; Ling, M. Curcumin protects radiation-induced liver damage in rats through the NF- $k B s i g n a l i n g$ pathway. BMC Complementary Med. Ther. 2021, 21, 10.

81. Anand, P.; Kunnumakkara, A.B.; Newman, R.A.; Aggarwal, B.B. Bioavailability of curcumin: Problems and promises. Mol. Pharm. 2007, 4, 807-818. [CrossRef]

82. Shi, H.S.; Gao, X.; Li, D.; Zhang, Q.W.; Wang, Y.S.; Zheng, Y.; Cai, L.L.; Zhong, R.M.; Rui, A.; Li, Z.; et al. A systemic administration of liposomal curcumin inhibits radiation pneumonitis and sensitizes lung carcinoma to radiation. Int. J. Nanomed. 2012, 7, 2601-2611.

83. Jäger, R.; Lowery, R.P.; Calvanese, A.V.; Joy, J.M.; Purpura, M.; Wilson, J.M. Comparative absorption of curcumin formulations Nutr. J. 2014, 13, 11. [CrossRef] [PubMed]

84. Singh, S.P.; Sharma, M.; Gupta, P.K. Cytotoxicity of curcumin silica nanoparticle complexes conjugated with hyaluronic acid on colon cancer cells. Int. J. Biol. Macromol. 2015, 74, 162-170. [CrossRef] [PubMed]

85. Jyoti, K.; Bhatia, R.K.; Martis, E.A.F.; Coutinho, E.C.; Jain, U.K.; Chandra, R.; Madan, J. Soluble curcumin amalgamated chitosan microspheres augmented drug delivery and cytotoxicity in colon cancer cells: In vitro, and in vivo, study. Colloids Surf. B Biointerfaces 2016, 148, 674-683. [CrossRef]

86. Shinde, R.L.; Devarajan, P.V. Docosahexaenoic acid-mediated, targeted and sustained brain delivery of curcumin microemulsion. Drug Deliv. 2017, 24, 152-161. [CrossRef]

87. Choi, Y.H.; Han, D.H.; Kim, S.W.; Kim, M.J.; Sung, H.H.; Jeon, H.G.; Jeong, B.C.; Seo, S.I.; Jeon, S.S.; Lee, H.M.; et al. A randomized, double-blind, placebo-controlled trial to evaluate the role of curcumin in prostate cancer patients with intermittent androgen deprivation. Prostate 2019, 79, 614-621. [CrossRef]

88. Lanjekar, A.B.; Bhowate, R.R.; Bakhle, S.; Narayane, A.; Pawar, V.; Gandagule, R. Comparison of efficacy of topical curcumin gel with triamcinolone-hyaluronidase gel individually and in combination in the treatment of oral submucous fibrosis. J. Contemp. Dent. Pract. 2020, 21, 83-90.

89. Delavarian, Z.; Pakfetrat, A.; Ghazi, A.; Jaafari, M.R.; Homaei, S.F.; Dalirsani, Z.; Mohammadpour, A.H.; Rahimi, H.R. Oral administration of nanomicelle curcumin in the prevention of radiotherapy-induced mucositis in head and neck cancers. Spec. Care Dent. 2019, 39, 166-172. [CrossRef]

90. Pinheiro, S.L.; Bonadiman, A.C.; Borges-Lemos, A.L.; Annicchino, B.M.; Segatti, B.; Pucca, D.S.; Dutra, P.T.; de Carvalho, E.; Silva, R.M.; Leal, F. Photobiomodulation Therapy in Cancer Patients with Mucositis: A Clinical Evaluation. Photobiomodulation Photomed. Laser Surg. 2019, 37, 142-150. [CrossRef] 